\title{
Mango malformation: A fungal disease, physiological disorder or malady of stress
}

\author{
Avneet Kaur* and Nirmaljit Kaur \\ Department of Botany, Punjab Agricultural University, Ludhiana-141004 (Punjab), INDIA \\ *Corresponding author. E-mail: avneetkhalsa08@gmail.com \\ Received: October 23, 2017; Revised received: December 4, 2017; Accepted: February 13, 2018
}

\begin{abstract}
Mango (Mangifera indica L.) is one of the important commercial crops occupying a prominent place among various fruit crops. Mango malformation is a crucial malady in mango production leading to heavy economic loss. Malformation occurs in vegetative as well as floral tissue, later being virulent leading to loss of entire crop. Fusarium moniliforme is suggested as dominant causal agent of the disease although association of 'stress ethylene' with disease occurrence has also been studied. Fungal pathogens responsible for the malady are known to elevate the level of 'stress ethylene' in malformed plants. Various reports have been put forward to explain the etiology and control measures of the disease but nature and management of the disease is still a mystery. Hence, the present review aims at offering information regarding aspects of development and management of mango malformation.
\end{abstract}

Keywords: Abiotic and biotic stress, Fusarium, Mango malformation, Stress ethylene

\section{INTRODUCTION}

Mango (Mangifera indica L.) acknowledged as "king of fruits" is one of the finest fruits having great cultural and religious significance. This crop belonging to family Anacardiaceae originated in the Indo-Burma in the sixteenth century. Tropical and sub-tropical areas favour the production of this crop. About 1500 varieties of mango have been reported. Among these varieties, 1200 are found in India (Krishnan et al., 2009). As per reports, mango production is next to banana on the global basis (NBH, 2004 and Krishnan et al., 2009). In the world, India ranks first in the production (18.643 million tonnes/hectare) and cultivation area (2.209 hectare) of mango (NBH, 2016). Although the production as well as cultivation areas of mango crop are higher, mango productivity is still low (6.3 million tonnes/hectare) due to various factors (biotic and abiotic) affecting its growth. Mango malformation is the serious threat among these leading to reduction (40$80 \%$ every year in India) in the mango production (Kumar et al., 2011; Kumar and Misra, 2016 and Raj et al., 2017).

Mango malformation: Mango malformation is reported to be one of the most deleterious diseases of mango in environment (Ploetz, 2001 and Rymbai and Rajesh, 2011). At present, mango malformation has been assigned as plant disease of international acclaim. This malady described as a fungal disease and a physiological disorder, was first reported in Darbhanga (Bihar, India) by Marries (Watt, 1891). Since its occurrence, mango malformation has been reported across many countries in the world including Australia, Brazil, Cuba, Egypt, South Africa, United States of America, United Arab Emirates, Bangladesh, etc. In India, northwest regions are more prone to the disease (Ploetz et al., 1999; Rymbai and Rajesh, 2011 and Freeman et al., 2014). Gujarat, Maharashtra, Punjab, Himachal Pradesh, Madhya Pradesh, Uttar Pradesh, Jammu and Kashmir, Bihar and Haryana are also affected by this disease (Krishnan et al., 2009; Kumar et al., 2011 and Freeman et al., 2014). The maximum economic loss reported in India is 86\% (Kumar et al., 1993 andRymbai and Rajesh, 2011).As per studies, mango malformation can be defined as fungal disease of mango caused by Fusarium species leading to abnormal growth of vegetative shoots and inflorescence (Kvas et al., 2008). With the occurrence of disease, crop shows heavy damage as inflorescence fails to produce fruits. The acuteness of the disease may differ from variety to variety and cycle to cycle. Within a variety also, severity of disease may vary from tree to tree (Kumar et al., 2011 and Rymbai and Rajesh, 2011). Crop damage may vary from $50-60 \%$ to $100 \%$ depending upon the severity of the disease (Summanwar, 1967). Mango malformation has been noticed worldwide and one of the major reason for widespread interest in this malady is that mango is an important commercial crop and only known host of the disease. In spite of large cultivation area, malformation limits the mango production by $50-60 \%$ (in severe cases $100 \%$ ), hence, causes great economic loss. Direct yield loss occurs every year as 
malformation in the floral tissue produce malformed and sterile bunches, hence, no fruit set. Mango malformation disease is endemic as plants once affected remain diseased. Etiology, epidemiology and effective control measures are not accurately known due to paucity of information regarding the disease. Mango market also gets affected with the curtailment on the export of mango saplings from affected area. At present, the malady has been spread to other mango growing countries around the world. In India, majority of commercial mango varieties are severely affected (Chakrabarty, 2011 and Ansari et al., 2015). Mango malformation has been observed on saplings, seedlings as well as floral organs (Iqbal et al.,2004 andRymbai and Rajesh, 2011). The disease produces hypertrophied tissue in both the vegetative shoot and inflorescence. Vegetative malformation retards the canopy development whereas the floral malformation leads to economic loss as malformed inflorescence do not bear the fruits (Freeman et al., 2014).It can be classified into two distinct classes:

Vegetative malformation: Vegetative malformation mainly affects young seedlings in nurseries. Malformation involves appearance of small shoot lets possessing small scaly leaves, forming a bunch like appearance on shoot apices. In nurseries, seedlings especially growing beneath the canopy of the diseased area and young trees are mainly affected. These young seedlings get affected at an early age. Malformation has been observed even in 3-4 months old plants (Rymbai and Rajesh, 2011). Symptoms of disease include compactly bunched, hypertrophied young shoots accompanied by swollen apical and lateral buds (Ploetz et al., 2002 and Youssef et al., 2007). These numerous swollen vegetative buds constitute the hypertrophied tissue. Apical dominance is lost and shoot growth is impeded. Multi-branched shoot apex possessing scaly leaves and distorted terminals with short internodes is termed as "Bunchy Top" and "Witch's Broom" (Ploetz, 2004). "Bunch Top" may be produced either at apex or beneath leaf axil. Leaves are narrow and brittle that may bend towards the supporting system. As the shoot does not expand fully, it gives a tight bunch appearance. Seedlings affected by the disease at early stage remain stunted and do not survive, but seedlings infected later may resume normal growth above the infected areas (Krishnan at al., 2009 and Rymbai and Rajesh, 2011).Vegetative malformation causes the maximum effect (90.9\%) in 4-8 years old trees (Rymbai and Rajesh, 2011).

Floral malformation: When the malformation occurs in the panicles and affects the inflorescence, it is referred to as floral malformation. Since fruit does not set in the affected inflorescence, it is more serious in comparison to the vegetative malformation (Mahrous, 2004). Rachises (primary, secondary as well as tertiary) become short, thick and highly branched or hy- pertrophied. Panicles with the increased branching become greener and heavier. Panicles infected by the disease possess the unopened flowers. Flowers are usually male and rarely bisexual. Malformed perfect or bisexual flowers bear exceptionally enlarged and nonfunctional ovary. Bisexual flowers may show poor pollen viability or sterile pollens. Ovary may be fertilised in some cases but will eventually abort (Ploetz, 2004 and Rymbai and Rajesh, 2011). Malformed panicles are reported to possess more flowers (one to three times) than the healthy panicles. Healthy and malformed flowers may occur on same panicle or same shoot. Phyllody i.e. development of dwarf and distorted leaves is also observed in the malformed panicles. On the basis of severity of disease and compactness of panicle, the malformed panicles can be classified as heavy, medium and light type (Kumar et al., 2011). In heavy type, large masses of flowers occur that may dry up and remain attached as brown discoloured bunches while other grow till the next season. They are compact and overloaded due to large flowers. They produce brownish fluid and possess flowers even after the fruit set has occurred in the healthy panicles (Ram and Yadav, 1999). The yield reduction in heavily malformed panicles is $90 \%$ due to either no fruit set or immediately aborting fruit after they have set (Ploetz, 2001, Kumar et al., 2011).The medium type is less compact and remains attached to plant for longer period than the healthy panicles. The light type does not remain attached on plant and is slightly more compact than healthy panicle (Krishnan et al., 2009 and Kumar et al., 2011).

Susceptibility and resistance to mango malformation: The occurrence of mango malformation in mango varieties is dependent upon the various factors such as temperature, time, age of tree, etc. The early blooming varieties are more susceptible to the disease than the late blooming varieties (Krishnan et al.,2009 and Kumar et al., 2011). Young plants (91\% incidence in 4-8 years plant) are more prone to disease attack than older ones $(9.6 \%$ incidence $)$ as per reports (Kumar et al., 2011). In early years of plant growth, level of polyphenol oxidase (PPO) could be correlated to the synthesis of phenolic compounds providing information about the susceptibility or resistance to inflorescence malformation (Sharma et al., 1994 and Krishnan et al.,2009). Depending upon susceptibility and resistance to the disease and based on the PPO activity, phenolic content and panicle formation twenty fourmango cultivars were categorized into five types by Krishnan et al.,(2009).Bhadauran and H-8-1 were rated as highly resistant, Dashehari, Kurukkan, Langra and Fazli as moderately resistant, Sensation, Rataul, Eldon, Mallika and Alphonso as susceptible, Lalsundri, Red small, H-31-1, Totapari, Neelum, Himsagar, Extreme, Eward, Zill and Amarpali as moderately susceptible and Chausa, Tommy Atkins, Zardalu and Rat- 
na as highly susceptible.

Etiology and factors correlated to mango malformation: For more than 100 years, scientists have been working for knowing the causes and control measures of the disease (Haggaget al., 2010). Studies have not yet clearly disclosed the etiology of mango malformation although various claims regarding its association with biotic factors such as fungal pathogen, virus and mite have been made (Rymbai and Rajesh, 2011). It was first reported that a fungus in Gibberellafujikuroi identified as Fusarium moniliformeto be responsible for the malformation of panicles. Later, its role in vegetative malformation was also found (Freemanet al.,2014). Fusarium sterilihyphosum, F. mexicanu$m$ and $F$. tupiense were found to be the other causative agent of the disease. In addition to these, abiotic (temperature, $\mathrm{C} / \mathrm{N}$ ratio of shoots, plant growth regulators, malformin and mangiferin) are also correlated with occurrence of mango malformation (Kumar et al., 2011).

Abiotic Factors: Abiotic factors directly or indirectly affect the incidence of the malformation disease. These environmental, nutritional and physiological aspects can affect the occurrence of disease in one way or other (Kumar et al., 2011 and Rymbai and Rajesh, 2011).

Temperature: Studies have revealed a correlation between temperature and occurrence of mango malformation as seasonal variation in temperature at the time of flowering affects the intensity of malformation. In north-west India the disease is severe (at $10-150^{\circ} \mathrm{C}$ ), mild (at $15-20^{\circ} \mathrm{C}$ ), sporadic (at $20-25^{\circ} \mathrm{C}$ ) and nil (over $25^{\circ} \mathrm{C}$ ) depending upon the mean temperature during flowering (Kumar et al., 2011). Occurrence and severity of the disease can be correlated with ambient temperature at the time of flowering. As, in Egypt, the panicles appearing in the spring shoots were found to most severely affected (Rymbai and Rajesh, 2011).

Metabolic imbalance: $\mathrm{C} / \mathrm{N}$ ratio was found to be higher in the malformed tissue than the healthy ones. It was thought to be responsible for the higher production of staminate flowers on the malformed panicles and preventing the flower and fruit development. Contrarily, except for fully swollen bud stage, low $\mathrm{C} / \mathrm{N}$ ratio was observed in malformed shoot as well as panicles at all development stages. It was suggested to be due to excessive utilization of carbohydrates for the growth of malformed panicles (Kumar et al., 2011).

Plant growth hormones: Plant growth hormones are also thought to be involved in incidence of disease. Auxin level is higher in the healthy panicles and shoots bearing them in comparison to the malformed tissue. Decrease in auxin level results in hormonal imbalance causing malformation. Contrary results have also been reported in malformed panicles that contain higher level of auxins. Cytokinin concentration was found to be higher in malformed panicles in comparison to thehealthy ones. Gibberellins activity may vary depending upon the development stage, location and variety. Inhibitory activity of abscisic acid was more in malformed panicles than in healthy panicles (Kumar et al., 2011). Among plant hormones, ethylene is considered to be the most important because symptoms of malformation are thought to be produced by the 'stress ethylene' (Singh, 2000; Bains and Pant, 2003 and Ansari et al., 2015). In addition, the causal agents of the disease are also reported to increase the concentration of ethylene (Pant, 2000 and Ansari et al., 2015).

Malformin and Mangiferin: Mangiferin is a nontoxic polyphenol and a normal metabolite that accumulates during the mango malformation. Mangiferin checks the secretion of fusaric acid by the Fusarium. Polyphenol oxidase, a mangiferin degrading enzyme increases its activity in the malformed tissues (Kumar and Chakraborty, 1992). High mangiferin concentration, degraded carotenoids and toxic metabolites of Fusarium species are found to play a role in the malformation disease incidence (Krishnan et al., 2009). It is reported that Malformin-like substances and mangiferin have high concentration in the malformed panicles whereas trace amount or complete absencehas been observed in the healthy panicles. Antimalformins such as ascorbic acid, glutathione and silver nitrate when applied to panicles caused disappearance of malformin and induced fruiting like healthy panicles (Kumar et al., 2011). Accumulated mangiferin increases the IAA content, chlorophyll and photosynthesis leading to more vegetative growth, greener malformed shoots/panicles and more carbohydrate synthesis respectively. Mangiferin also reduces respiration, catabolism and transpiration leading to metabolic imbalance $(\mathrm{C} / \mathrm{N}$ ratio), more longevity and high moisture content respectively (Chakarabarti and Kumar, 2002; Krishnan et al., 2009; Rymbai and Rajesh, 2011).

Biotic factors: Although different biotic factors such as virus, mite and fungus have been suggested correlating with the occurrence of malformation, fungus is found to be the causal agent for mango malformation. Occurrence of fungus and its asscociation with malformation was reported for first time in 1966, insuring its pathogenicity (Summanwaret al., 1966). This fungus was isolated from the malformed plants and identified as Fusarium moniliforme (Kumar et al., 2011).In an orchard, both healthy and malformed inflorescence can be reported simultaneously. Further the formation and occurrence of conidia on malformed tissues insures its association with malformation disease. Conidia count was found to increase from bud break stage to bud maturation stage in the malformed tissue. Fusarium mangiferae, another causative agent of mango malformation disease produces microconidia on live and dead malformed tissues. The distribution of F.mangiferae in the diseased tree suggests that apical buds are primary sites of infection (Gamliel-Atinskyet al., 2009 and Freeman et al., 2014). This was confirmed by another 
experiment in which mango was artificially inoculated with isolates of F.mangiferae (Freeman et al., 1999 and Freeman et al., 2014).

Ploetz proposed a disease cycle that involves the fungus, F.mangiferaeand bud mite A.mangiferae in the development and spread of malformation disease (Ploetz, 2001 and Freeman et al., 2014). Vegetative growth and malformed panicles acts as source for pathogen conidia. Three different routes were suggested that favours the conidia to reach the site of infection:

Through wind or aerial dissemination

Via contaminated bud mites (A.mangiferae) or

Via infected material from host plant that falls into funnel-like structure of the apical bud of healthy plant

Except arid areas, conidia can also be transported via dew droplets, rain or irrigation splash (moistureassisted dissemination). Withatleasttwo hours of wetness and $5-41^{\circ} \mathrm{C}$ temperature, conidia germinate and infection can occur. The process can be accelerated with the increase in duration of wetness (more than 3 hours) and temperature range from $15-30^{\circ} \mathrm{C}$. The frequency and severity of disease could be increased by the presence of A.mangiferae (Gamliel-Atinsky et al., 2009). After penetration, the buds are colonized by the pathogen and show the symptoms depending upon the level of colonization (Ploetz, 2001 and Freeman et al., 2014).

Another model suggesting the development of diseased tissue either through natural or unnatural (eg. use of infected scion material) ways was proposed. The affected tissues serve as the sources of inoculum for infecting the pathogen free sites. The primary infective propagule of pathogen i.e. micro conidia are formed in the infected area and are dispersed through the wind to be deposited on the same or different trees in same or other orchard. The new plantation in the area near to the infected orchard may get infected and the later serve as a source of inoculums (GamlielAtinsky et al., 2009 and Freeman et al., 2014). This model was proposed with an important implication that window of infection is also window of protection during which fungicides should be applied to control the disease. It suggests that reduction of primary inoculum could be achieved by complete removal of malformed tissue until flowering halts (Freeman et al., 2014). Also, spread of malformation disease is thought to occur by grafting that offers the disease to move into new areas (Kumar et al., 1993andRymbai and Rajesh, 2011). It has been reported that in Egypt production fields, non-grafted seedlings are cultivated beneath the mango trees possessing malformed tissues (Ploetz et al., 2002). The spread of disease has been clearly demonstrated in some areas including nurseries, infected nursery stocks and mango bud mite whereas within-tree and tree-to-tree dissemination of pathogens in nurseries and orchids is not yet clear
(Ploetz, 2004;Haggag, 2010andRymbai and Rajesh, 2011).

The fungus correlated with the disease produce macroand microconidia that are the infective propagules. It is suggested that the pathogen is neither soil-borne nor seed-borne because as per reports conidia declined rapidly in the soil (under controlled and outdoor conditions) and no infection was detected on the seed and seed coat of fruit harvested from the infected trees (Freeman et al.,2004). The infection of pathogen may occur via root that colonizes the root system of the seedling. The infection becomes systemic and spreads to the apical part of plant including apical buds (Haggag, 2010). The fungus may release the secondary metabolites, create hormonal imbalance and restrict the normal growth of meristematic tissues in the apical buds. Fungus closer to the vascular channel of host plant may compete for nutrients with the apical bud, thus, resulting in the lower uptake of assimilates by malformed buds (Freeman et al., 2004and Rymbai and Rajesh, 2011).

A large number of mango bud mites (Eriophyesmangiferae) can be observed on the malformed plants that are suggested to play an important role in the malformation (Ploetz, 2004). These contaminated bud mites are reported to act as a vector of Fusarium species on its body, hence, disseminate the fungus. While feeding on the epidermal cells of vegetative and floral tissues of mango wounds are created that may facilitate the entry of pathogen into the host plant (Haggag, 2010). However, use of acaricides failed to control the disease and role of mites in the disease occurrencehas not been proved (Yadav, 1999andRymbai and Rajesh, 2011). Earlier, the disease was considered of viral nature due to viral disease like symptoms and failure in isolating any pathogenic organism. Later, as no success was obtained in transmitting the disease from branches to seedlings, seedlings to seedlings and seedlings to scions by grafting, inoculation and budding, it was suggested that mango malformation is not of viral etiology (Kumar et al., 2011).

Ethylene and mango malformation: 'Stress ethylene' is proposed to be responsible for the mango malformation suggesting the synthesis of stress ethylene at a high rate upon perceiving a response from stressful environment (Pant,2000; Krishnanet al., 2009; Jouyban, 2012 and Ansari et al., 2015). In the malformed trees, stress ethylene production shows various physiological responses including leaf epinasty, suppression of apical dominance, abscission, aerenchyma formation, degenerated root, hypertrophy of lenticels, flower-fall from inflorescence, increased gummosis and necrosis (Rymbai and Rajesh, 2011 and Ansari et al., 2015). These symptoms may be correlated with the increased production and accumulation of biochemical metabolites. Factors correlated with mango malformation such as fungal pathogens, insect infestation, viruses, exces- 
sive soil moisture, chemical stimuli (eg. metal ions), gases (eg. $\left.\mathrm{SO}_{2}\right)$ and herbicidies are reported to increase the stress ethylene. Fusariummangiferae has also been reported to cause the disease via producing ethylene themselves (Ansari et al., 2004 and Ansari et al., 2015). In mango plants, level of ethylene synthesis byproducts such as methionine, ascorbate, cyanide and inorganic phosphate suggested that ethylene biosynthesis pathway sustains in mango plants (Nailwal et al., 2006). In Dashehari, high level of ethylene has been reported in the malformed panicles at different stages of development including bud inception (145\%), full grown panicle prior to full bloom $(67 \%)$, fully swollen buds (46\%) and full grown panicle at full bloom (34\%) (Freeman et al., 2014).

Stress ethylene also leads to accumulation of toxic levels of cyanide in malformed plant. Cyanide can be detoxified by $\beta$-Cyanoalanine synthase ( $\beta$-CAS, cyanide detoxification enzyme) by converting it into $\beta$ cyanoalanine. However, level of $\beta$-CAS is reported to be low in malformed tissues as compared to heathly tissues. Possibility of occurrence of cyanide insensitive respiration suggests hindrance of the normal respiration, hence, necrosis and death of malformed tissue. Presence of black mitochondria and necrotic cells in the malformed tissues was observed that could be due to presence of high concentration of cyanide in the malformed tissue (Kukreja and Pant, 2000; Kaushik,2002;Rymbai and Rajesh, 2011 and Ansari et al., 2015).

In malformed panicles, germination and growth of pollen is limited by presence of fused lobed anthers, impaired pollen grains and hooked stigma with poor receptivity. This aborted morphology is thought to be the result of increased endogenous ethylene that leads to malfunction in the fruit development. During oversensitive reaction of plants,cyanide also adds to effect by promoting the necrosis,thus, dehydration of the anther and pistil (Singh et al., 2014). Therefore, it is suggested that death of malformed tissues of mango is due to excessive cyanide production and stress ethylene (Freeman et al., 2014). Recently, it has been confirmed that purescine could eliminate the negative effect of ethylene, hence, reduce the malformation in mango flower (Singh et al., 2014). Thus, mango malformation can be reduced by controlling the ethylene actions in the plants. In Phillipines and India, growers sometimes maintain smoky fires during vegetative flush in mango orchards to induce healthy flowering. This result could be attributed to the fact that smoke elevates the temperature and carbon dioxide thus mitigating the ethylene production and reducing mango malformation (Ansari et al., 2015).

Disease management: Although little or no success is obtained in controlling the disease various methods have been put forward for the disease management. These control measures have shown variable results by reducing the disease in some orchards and not in others (Chakrabarti, 1996). Mango management strategies vary among different mango-producing countries (Freeman et al., 2014). Following measures including use of plant growth regulators, insecticides, pesticides and biopesticides, deblossming, pruning of malformed areas, etc alone or in combinationhave resulted in control of disease to some aspect (Kumar et al., 2011 and Kumar and Misra, 2016).

Malformation is correlated with occurrence and timing of flowering in plants. If plants are foliar sprayed with the chemicals, disease can be reduced as it delays or advances the inception of flowering. Auxins and gibberellins are reported to reduce the malformation of panicles when applied at flower bud differentiation stage (Kumar et al., 2011). Foliar spray of Napthalene acetic acid (100ppm or 200ppm) and application of benomyl control of disease in October reduced the disease incidence at high level (Mahrous, 2004 andRymbai and Rajesh, 2011). Prior to flower bud differentiation, application of Naphthalene Acetic Acid (100ppm) and Indole-3-Butyric Acid (200ppm) reduced the incidence of floral malformation (Rymbai and Rajesh, 2011). Anti-malformins like ascorbic acid, silver nitrate, glutathione, potassium metabisulfite and Naphthalene Acetic Acid when applied leads to formation of healthy panicles (Kumar et al., 2011). However, application of these chemicals should be minimized as these could be toxic at high concentration and when used for longer durations. For example, potassium metabisulfite is known to be hazardous to human health causing serious eye irritation, skin irritation and other respiratory irritations.

The most common approach is to remove and destroy the characteristic tissue showing the symptoms of mango malformation disease.Pruning removes the shoot tip that accumulates malformation inducing principle (Kumar et al., 1993). In Dashehari, moderate pruning of $20 \mathrm{~cm}$ shoot bearing malformed panicles in January (at panicle emergence state) leads to suppression of disease (Sirohi et al., 2009). Usually, pruning involves removal and burning of infected terminals and subtending three nodes. The disease occurrence could almost be diminished if this method is followed for 2-3 consecutive years. It is recommended that once the disease is reported in the orchard, symptomatic tissues should be removed to limit the occurrence of disease. (Muhammad et al., 1999 and Ploetz, 2011). This sanitation practice leads to reduction in mango malformation by limiting the inoculums. However, it is difficult to impose on the large trees with panicles that are difficult to access. This practice is recommended commercially as control measure in the South Africa and United States (Kumar et al., 2011; Rymbai and Rajesh, 2011 and Freeman et al., 2014).

Use of insecticides, fungicides and plant growth regulators in combination with pruning is an effective way 
of reducing the level of inoculum in the orchard and to control the mango malformation disease (Ploetz,2001 and Rymbai and Rajesh, 2011). Fungicides such as benzimidazoles, Topsin-M, etc when applied were found to reduce the mango malformation but statistical significance was not demonstrated (Iqbal et al., 2011 and Freeman et al., 2014).

Use of biopesticides was found effective in limiting the growth of Fusariummoniliforme, a causative agent of mango malformation. Three species of Trichoderma (Trichoderma viride, Trichoderma virens and Trichoderma harzianum) were tested and found effective against the fungus (Kumar et al., 2011).

At bud burst stage, deblossoming was found effective in controlling the disease. Deblossoming alone or in combination with NAA (200 ppm) spray leads to reduction of malformation (Kumar et al., 2011).

Chemicals including sulphates of cobalt, nickel and cadmium were reported to moderately control the disease but were thought risky to apply on food items (Singh et al.,1994). In Keitt tree trunk, fosetyl-Al was injected and found to reduce the floral malformation from 96 to $48 \%$ but no effect on fruit yield (Freeman et al., 2014).

Chelates such as mangiferin $\mathrm{Zn}^{++}$and mangiferin $\mathrm{Cu}^{++}$ are suggested to reduce the concentration of mangiferin and restore the biochemical function if sprayed on the infected area in the malformed plant, hence, control the mango malformation (Rymbai and Rajesh, 2011).

Severity of the disease could be lowered by following integrated management packages such as sanitary pruning, weed control, irrigation management, control of vectors, adding organic matter to the soil, balanced chemical fertilization, promoting anticipated blooming and protection of new buds (Rymbai and Rajesh, 2011).

There is a need to establish new plantings with pathogen-free nursery stock. Nurseries must be away from the infected area and scions of diseased plants should not be used at any cost. Appearance of malformed plant should be followed by immediate removal. This practice is common in two most severely infected areas i.e. Egypt and India (Ploetz, 2001andRymbaiand Rajesh, 2011).

The disease occurrence can be reduced by preferring breed resistant cultivars rather than susceptible cultivars. In epidemic prone areas, alternate bearing and late flowering varieties should be selected for cultivation (Pant, 2000andRymbai and Rajesh, 2011).

PCR-based techniques could be used to prevent the entry of pathogen into new germplasm. This method (species-specific primers) can be used to find F. mangiferae in plants (Zheng and Ploetz, 2002; Youssef et al., 2009 and Rymbai and Rajesh, 2011).

\section{Conclusion}

In spite of long rigorous research of more than a century, control measures of malformation disease are still a mystery. Scientific research has been carried to find out the symptoms, causes, resistance and susceptibility to disease, disease management, etc. Fusarium speciesaresuggestedto be the dominant causative agent of disease. Molecular characterization is the need of present situation to identify the species of Fusarium associated with the disease. Genetic diversity analysis, study of gene expression of infected mango cultivars and use of disease resistant cultivars is required to minimize the occurrence of mango malformation. Disease resistant cultivars of mango should be identified and favoured over the susceptible ones for cultivation in orchards. Spread of disease can be avoided by reducing the transport of diseased plant parts to new areas and by destroying malformed plant parts at its origin. But more work needs to be done with respect to etiology, epidemiology and control measures of the disease as mango malformation is still prevalent worldwide leading to heavy economic loss.

\section{REFERENCES}

Ansari, M.W. (2004). Studies on the etiology of mango malformation: physiological and pathological perspectives. Ph.D. Thesis, G. B. Pant Univ. of Agric. \& Tech., Pantnagar.

Ansari, M.W., Rani, V., Shukla, A., Bains, G., Pant, R.C. and Tuteja, N. (2015). Mango (Mangiferaindica L.) malformation: a malady of stress ethylene origin. Physiol. Mol. Biol. Plants, 21(1): 1-8.

Bains, G. and Pant, R.C. (2003). Mango malformation: Etiology and preventive measures. Physiol. Mol. Biol. Plants, 9: 41-61.

Chakrabarti, D.K. (2011). Mango Malformation. Springer Press, NY, USA.

Chakrabarti, D.K. (1996). Etiology and remedy of mango malformation. In: Disease Scenario in Crop Plants. Vol. 1- Fruits and Vegetables. Agnihotri, V.P.; Prakash, O.; Kisbun, R. and Misra, A.K. (eds.). International Books and Periodicals Supply Service, Pitampura, Delhi, India. pp. 49-59.

Chakrabarty, D.K. and Kumar, R. (2002). Mango malformation: Present status and future strategy. In: Upadhyay, R.K., Arora, D.K. and Dubey, O.P. eds. IPM Systems in Agriculture.

Freeman, S., Maimon, M., and Pinkas, Y. (1999). Use of GUS transformants of Fusarium subglutinans for determining etiology of mango malformation disease. Phytopathology, 89: 456-461.

Freeman, S., Klein-Gueta, D. and Korolev, N. (2004). Epidemiology and survival of Fusarium mangiferae, the causal agent of mango malformation disease. Acta. Hort., 645: 487-491.

Freeman, S., Shitenberg, D. and Maymon, M. (2014). New insights into mango malformation disease epidemiology lead to a new integrated management strategy for subtropical environments. The American Phytopathological Society. Plant Disease, 98:11.

Gamliel-Atinsky, E., Freeman, S., Sztejnberg, A., Maymon, M., Ochoa, R., Belausov, E. and Palevsky, E. (2009). Interaction of Aceriamangiferae with Fusarium mangiferae, the causal agent of mango malformation disease. Phytopathology, 99:152-159. 
Haggag, W.M. (2010). Mango diseases in Egypt. Agric. Biol. J. N. Am., 1(3): 285-289.

Haggag,W.M., Hazza, M., Sehab, A. and Abd El-Wahab, M. (2010). Scanning electron microcopy studies on mango malformation. Nature and Sci., 8:122-127.

Iqbal, Z., Saleem, A. and Dasti, A.A. (2004). Assessment of mango malformation in eight districts of Punjab (Pakistan). Int. J. Agri. Biol.,6: 620-623.

Iqbal, Z., Akhtar, N., Ghazanfar, M.U., Shehzad, S.M., Ahmad, S., Asif, M., Yasin, M., Pervez, M.A., Dasti, A.A., and Saleem, A. (2011). Management of mango malformation through physical alteration and chemical spray. Afri. J. Agric. Res., 6:1891-1901.

Jouyban, Z. (2012). Ethylene biosynthesis. Tech. J. Engg. Appl. Sci., 1:107-110.

Kaushik, S.B. (2002). Studies on the etiology of mango (Mangiferaindica L.) malformation., Ph.D. Thesis, G. B. Pant Univ. of Agric. \& Tech., Pantnagar. pp.188.

Krishnan, A.G., Nailwal, T.K., Shukla, A. and Pant, R.C. (2009). Mango (Mangiferaindica L.) malformation an unsolved mystery. Researcher, 1:20-36.

Kukreja, S. and Pant, R.C. (2000). Role of cyanide in necrosis of malformed tissues of mango. Indian J. Hort., 57: 102-105.

Kumar, R. and Chakrabarty, D.K. (1992). Biochemical evidence of physiological specialization of Fusarium moniliformeSheld. The incitant disease of MangiferaindicaL. Indian J. Expt. Biol., 30: 448-450.

Kumar, J., Singh, U.S., and Beniwal, S.P.S. (1993). Mango malformation: One hundred years of research. Annual Review of Phytopathology, 31: 217-232.

Kumar, P. and Misra, A.K. (2016). Current Scenario of Mango Malformation and Its Management Strategies: An Overview. P. Kumar et al., (eds.), Current Trends in Plant Disease Diagnostics and Management Practices, Fungal Biology, pp.221-236.

Kumar, P., Misra, A.K. and Modi, D.R. (2011). Current status of mango malformation in India. Asian Journal of Plant Sciences, 10(1): 1-23.

Kvas, M., Steenkamp, E.T., Al-Aldwani, A.O., Deadman, M.L., Al-Jahwari, A.A. and Marasas, W.F.O. (2008). Fusarium mangiferae associated with mango malformation in Sultanate of Oman. Eur. J. Plant Pathol., 121:195-199.

Mahrous, H.A.H. (2004). Effect of spraying some chemical substances and a fungicide on floral malformation disease in mango. Acta Hort., 645: 481-486.

Muhammad, F., Ibrahim, M. And Pervez, M.A. (1999). Some physiological aspects of mango malformation. Int. J. Agri. Biol., 1: 94-96.

Nailwal, T.K., AnithaGomathi, K., Bains, G., Sand, N.K. and Pant, R.C. (2006). Mango (Mangiferaindica L.) malformatiom: Role of stress ethylene and cyanide. Physiol. Mol. Biol. Plants, 12(2): 131-134.

NBH (2004 and 2016). National Board of Horticulture

Pant, R.C. (2000). Is 'Stress ethylene' the cause of mango (Mangiferaindica L.) malformation? Physiol. Mol. Biol. Plant, 6: 8-14.

Ploetz, R.C. (2001). Malformation: a unique and important disease of mango, MangiferaindicaL. In Summerell, B. A., Leslie, J. F., Backhouse, D., Bryden W. L. and Burgess L. W. (eds), Fusarium: Paul E. Nelson Memorial Symposium (St Paul: APS Press), pp. 233-247.

Ploetz, R.C. (2004). The Major Diseases of Mango: Strate- gies and Potential for Sustainable Management. Acta Hort., 645: 137-150.

Ploetz, R.C., Haynes, J.L., VaaZquez, A. and Sattar, M.A.A. (1999). A preliminary studyon the causal agent of mango malformation in Egypt. Phytopathol., 89: S60 (abst).

Ploetz, R., Zheng, Q., Vazquez, A. and Abdel Sattar, M.A. (2002). Current status and impact of mango malformation in Egypt. Interntl. J. Pest Manag., (in press).

Ram, S. and Yadav, V.K. (1999). Mango malformation- a review. J. Appl. Hort. 1: 70-78.

Raj, R.S., Thakur, S.V., Vyas, Y.S., Patel, K.M., Patel, P.V., Joshi, M.N., Tyagi, S.N., and Bagatharia, S.B. (2017). Diversity analysis, pathogen load and gene expression studies of mango cultivars infected by mango malformation disease. Plant Growth Regulation, 81(1):117130

Rymbai, H. and Rajesh, A. M. (2011). Mango malformation: a review. Life Sci. Leaf., 22:1079-1095.

Sharma, R.R., Sharma, H.C. and Goswami, A.M. (1994). Polyphenol oxidase activity and phenolic content pattern during shoot development of grape (Vitis vinifera L.) in different growing seasons. J. Plant. Biochem. Biol., 3: 145-147.

Singh, Z. (2000). Hormonal physiology of mango malformation- an overview. Acta Hort., 525: 229-236.

Singh, A., Ansari, M.W., Singh, C.P., Shukla, A., Pant, R.C., Tuteja, N. and Bains, G. (2014). First evidence of putrescine involvement in mitigating floral malformation in mango: a scanning electron microscope study. Protoplasma,251(5):1255-1261.

Singh, Z., Singh, L., Arora, C. L., and Dhillon, B. S. (1994) Effect of cobalt, cadmium, and nickel as inhibitors of ethylene biosynthesis on floral malformation, yield, and fruit quality of mango. J. Plant Nutr. 17: 1659-1670.

Sirohi, S.C., Prakash, S., Rana, P. and Singh, R. (2009). Response of mango malformation to severity of malformed panicle bearing shoot pruning. Indian J. Hort., 66: 393-395.

Summanwar, A.S. (1967). Mango malformation: Serious economic consequences. Indian Hort., 11: 12-16.

Summanwar, A.S., Raychaudhuri, S.P., and Pathak, S.C. (1966). Association of the fungus Fusarium moniliformeSheld. with the malformation in mango (Mangiferaindica L.). Indian Phytopathology, 19: 227229.

Watt, G. (1891). Dictionary of economic products of India. 5:149. Govt. Printing Press, Calcutta.

Yadav, V. K. (1999). Mango malformation- a review. $J$. Appl. Hort., 1(1):70-78.

Youssef, S.A., Maymon, M., Zveibil, A., Klein-Gueta, D., Sztejnberg, A., Shalaby, A.A. and Freeman, S. (2007). Epidemiological aspects of mango malformation disease caused by Fusarium mangiferaeand source of infection in seedlings cultivated in orchards in Egypt. Plant Pathol.,56: 257-263.

Youssef, S. A., Shalaby, A. A., Sztejnberg, A., Maymon, M., Zveibil, A., Klein-Gueta, D. and Freeman, S. (2009). Malformation Presence in Mango Seedling Trees Cultivated within Infected Egyptian Orchards. Acta Hort., 820: 479-482.

Zheng, Q. and Ploetz, R. (2002). Genetic diversity in, and development of a PCR assay for identifying, the mango malformation pathogen. Plant Pathol., 51:208-216. 